\title{
THE EFFECT OF THE PANDEMIC ON THE CONSUMPTION OF ANIMAL PRODUCTS: THE CASE OF KAFKAS UNIVERSITY OF TURKEY
}

\author{
Erol AYDIN ${ }^{\star 凶}$ and Pinar AYVAZOGLU DEMIR \\ Department of Animal Health Economics and Management, Faculty of Veterinary Medicine, Kafkas University, TR-36100 Kars, Turkey \\ Email: dr-erolaydin@hotmail.com; (D) ORCID: 0000-0001-8427-5658 \\ Supporting Information
}

ABSTRACT: The COVID-19 pandemic has brought about some changes in consumption preferences and nutritional habits as well as lifestyles of individuals, such as education, working system, and social relationships, especially due to having to stay at home. In this study, the change in animal food consumption dispositions of students who had to stay at home during the pandemic and received online education was examined compared to the pre-pandemic period. In the study, since face-to-face teaching-learning activities were suspended, an online questionnaire was used to collect the study data from a total of 380 students registered at Kafkas University. The average monthly income of the participants and the share they allocated to the total food and animal products expenditures in the budget were determined as $539.64 \pm 21.00 \$$, $132.73 \pm 5.08 \$$, and $62.18 \pm 2.67 \$$, respectively. Although the annual chicken meat consumption amount did not change according to the income levels of the students, it was determined that the consumption of animal products, such as beef, mutton-lamb, milk-yogurt, cheese, and eggs increased as the income level increased. During the pandemic period, the food consumption of $55.3 \%$ of the participants and the animal products consumption of $35.8 \%$ increased. On the other hand, it was determined that the consumption of food and animal products increased as the income level increased during the pandemic compared to the prepandemic period. During the pandemic period, it was determined that red meat and salami-sausages

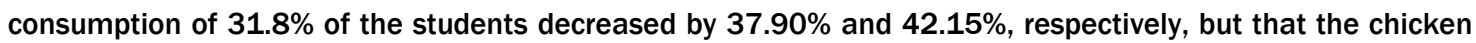
meat consumption of $31.3 \%$ of the students and milk and dairy products consumption of $37.9 \%$ increased by $31.02 \%$ and $39.17 \%$, respectively. As a result, it was determined that there were significant changes in the nutritional habits of the students during the COVID-19 pandemic, and it was determined that there were significant increases in the consumption of animal products other than red meat. The primary reason why red meat consumption did not increase is thought to be due to the high price of the product compared to consumers' income levels.

Keywords: Animal Products, Consumption, COVID-19, Meat, Pandemic.

\section{INTRODUCTION}

The pandemic, which was caused by the coronavirus and called the COVID-19 pandemic, was first seen in December 2019. The World Health Organization (WHO) declared COVID-19 as a high-risk global pandemic across the world on March 12, 2020 (Andrews et al., 2020). The first case in Turkey was reported on March 11, 2020, and measures were taken across the country gradually due to the increase in the number of cases. The most important measure taken was lockdowns. In this context, a partial and/or full closure was put into effect across the country as of April 29,2020 (TR Ministry of Health, 2020).

The COVID-19 pandemic has brought about several changes in consumption preferences and nutritional habits as well as lifestyles of individuals, such as education, working system, and social relationships, especially due to having to stay at home (Dilber and Dilber, 2020; Ersoy and Yardimci, 2020; Taskin et al., 2020). The concept of healthy eating has come to the fore in society to protect against COVID-19 and improve the immune system (Andrews et al., 2020; Saul, 2020; Zhang and Liu, 2020). A healthy diet can be achieved by an adequate and balanced intake of nutrients that meet the energy needs of the body. When nutrients are not taken adequately or taken more or less than necessary, growth and development will stop and the health of the person will gradually deteriorate (Dilber and Dilber, 2020). Nutrition does not only relate to health, but it is also a strategic issue. As a matter of fact, a country needs physically and mentally strong, healthy, and talented individuals to reach the desired social and economic level of civilization, which is closely related to balanced and healthy nutrition (Akin et al., 2019; Dilber and Dilber, 2020; Saul, 2020; Demir Ayvazoglu and Aydin, 2021). In this context, university students are at a critical age period, when their future eating habits are settled. In the study, the change in animal food consumption dispositions of students who had to stay at home during the pandemic and received online education was examined compared to the pre-pandemic period. The study was conducted to evaluate the nutritional habits of individuals in society during the pandemic period through the students of Kafkas University. 


\section{MATERIALS AND METHODS}

\section{Materials}

A total of $\mathbf{2 0 . 8 5 0}$ students were registered at Kafkas University in Kars, Turkey as of January 2021. It was not possible to reach the entire population; therefore, we decided to take a sample. The sample size was determined as at least 378 individuals based on a $5 \%$ margin of error and $95 \%$ confidence interval. Since face-to-face education was suspended due to the COVID-19 pandemic, the study data were collected by using an online questionnaire form created on docs.google.com. The questionnaire was applied to a total of 400 students between February 7 and March 31, 2021, considering that there may be reasons limiting the study, such as missing data. Eventually, 380 questionnaires were included in the study due to missing data on some questionnaires.

\section{Methods}

Research methods consist of research design, data access, data analysis, and evaluation.

\section{Data analysis}

The analysis of the study data was conducted on the SPSS software package (Version: 23.0; IBM, USA). Descriptive statistics of variables, such as demographic information and nutritional habits of the research group, were performed and presented in tables. While doing the analysis and interpretation of the data, the Chi-square test was used to analyze categorical data, and the One Way ANOVA test (one-way analysis of variance) was employed to determine the relationships between monthly household income and animal products expenditures and consumption amounts. Tukey test was used to determine the differences between the groups, and $P<0.05$ was taken as the level of significance.

\section{RESULTS AND DISCUSSION}

Consumption of animal products is one of the basic needs for a balanced and healthy diet and is indispensable for the development of society and economy and the sustainability of development. In this respect, easy access to animal products at affordable prices and quality is the most important goal of developed and developing countries, but access to such healthy foods by all segments of society cannot be provided at an affordable price and in adequate quantity (Akin et al., 2020). Some demographic data of the students participating in the study are given in Table 1.

As seen in Table 1, 46.6\% of the participants were male, 53.4\% were female, $52.9 \%$ came from the provinces in the Eastern and Southeastern Anatolia Regions, the fathers of the $58.9 \%$ were illiterate or primary/secondary school graduates. The data about the monthly household income level of the students and their monthly animal product expenditures are given in Table 2.

As seen in Table 2, the expenditures of the participants on milk and dairy products did not change significantly according to their income level, whereas the share allocated to animal products, namely red meat, chicken meat, and fish, especially by those with a monthly income level above $\$ 900$, increased, which was statistically significant $(P<0.001)$. This situation can be explained by "Engel's Law". As a matter of fact, red meat is characterized by high production costs and high output prices compared to other food products and can be considered a luxury food item (Charlebois et al., 2016; Aktas, 2020). In this context, as the income level increases, the demand for red meat increases, as well. Parallel to the results of the current study, many studies have reported that there is a significant relationship between the average monthly household income groups and the quantity of animal products purchased (Celik and Sengul, 2001; Sengul, 2002; Seker et al., 2011).

It was determined that the average monthly income level of the participants was $539.64 \pm 21.00 \$(X \pm S E M)$, they spent $25 \%(132.73 \pm 5.08 \$)$ of their budget on food, and that $46.85 \%(62.18 \pm 2.67 \$)$ of their food expenditure was allocated to animal products. According to the data obtained from the survey, of the monthly animal product expenditures, $19.99 \%$ was allocated to red meat, $13.30 \%$ to chicken meat, $6.76 \%$ to fish, and $6.79 \%$ to milk and dairy products.

The household income levels of the students and their annual consumption of animal products are given in Table 3. As seen in Table, the students participating in the study consumed an average of $9.31 \mathrm{~kg}$ of beef, $5.89 \mathrm{~kg}$ of muttonlamb, $16.94 \mathrm{~kg}$ of chicken meat, $37.38 \mathrm{~kg}$ of milk-yogurt, $20.84 \mathrm{~kg}$ of cheese, and 168.27 eggs per capita per year. In the study, it was determined that $75 \%$ of the students did not consume milk regularly, so the quantity of milk and yogurt consumption was evaluated together. In addition, the students' annual consumption of chicken meat did not change significantly according to their income levels; however, the annual consumption amount of animal products, namely, beef, mutton $(\mathrm{P}<0.05)$, milk-yogurt and eggs, was lower in those with a monthly income of $\leq 300 \$$ than the average and higher in those with a monthly income of $\geq 900 \$$ than the average, and this difference was statistically significant $(P<0.001)$. This situation can be explained by the high "Income Elasticity of Demand" in animal products, especially red meat, in all economic strata in Turkey. As a matter of fact, it can be said that the consumption shows a tendency towards red meat with the increase in income. In parallel with the results of the study, some studies have shown that there is a positive relationship between income level and red meat consumption (Aktas and Hatirli, 2010; Uzunoz and Karakas, 2014; Aktas, 2020). 
Table 1 - Some demographic data of the participants in present study.

\begin{tabular}{|c|c|c|c|}
\hline Parameter & & Frequency & Percent \\
\hline \multirow{3}{*}{ Gender } & Male & 177 & 46.6 \\
\hline & Female & 203 & 53.4 \\
\hline & Total & 380 & 100.0 \\
\hline \multirow{9}{*}{$\begin{array}{l}\text { Geographical region where } \\
\text { the student lives }\end{array}$} & Mediterranean & 32 & 8.4 \\
\hline & Eastern Anatolia & 138 & 36.3 \\
\hline & Aegean & 33 & 8.7 \\
\hline & Southeast & 63 & 16.6 \\
\hline & Central Anatolia & 41 & 10.8 \\
\hline & Black Sea & 26 & 6.8 \\
\hline & Marmara & 34 & 8.9 \\
\hline & Abroad & 13 & 3.4 \\
\hline & Total & 380 & 100.0 \\
\hline \multirow{6}{*}{ Education level of the father } & Primary school & 144 & 37.9 \\
\hline & Middle school & 72 & 18.9 \\
\hline & High school & 88 & 23.2 \\
\hline & University & 68 & 17.9 \\
\hline & Not literate & 8 & 2.1 \\
\hline & Total & 380 & 100.0 \\
\hline
\end{tabular}

Table 2 - Students' monthly household income levels and their monthly food and animal product expenditures (\$)

\begin{tabular}{|c|c|c|c|c|c|c|c|}
\hline Product expenditures & Income level* & $\mathbf{N}$ & Mean & Std. Error & Minimum & Maximum & F/P value \\
\hline \multirow{5}{*}{ Total food expenditures } & $\leq 300 \$$ & 112 & $81.44^{a}$ & 3.73 & 12.03 & 240.67 & \multirow{5}{*}{$\begin{array}{c}F=99.403 \\
P=0.000 \\
P<0.001\end{array}$} \\
\hline & $301-600 \$$ & 136 & $109.87^{b}$ & 4.71 & 12.03 & 240.67 & \\
\hline & $601-900 \$$ & 80 & $141.65^{c}$ & 9.38 & 24.07 & 421.18 & \\
\hline & $\geq 901 \$$ & 52 & $289.25^{d}$ & 18.79 & 18.05 & 722.02 & \\
\hline & Total & 380 & 132.73 & 5.08 & 12.03 & 722.02 & \\
\hline \multirow{5}{*}{ Red meat expenditures } & $\leq 300 \$$ & 112 & $16.42^{a}$ & 1.45 & .00 & 72.20 & \multirow{5}{*}{$\begin{array}{c}F=21.614 \\
P=0.000 \\
P<0.001\end{array}$} \\
\hline & $301-600 \$$ & 136 & $22.75^{a}$ & 2.317 & .00 & 180.51 & \\
\hline & $601-900 \$$ & 80 & $23.92^{\mathrm{a}}$ & 1.764 & .00 & 60.17 & \\
\hline & $\geq 901 \$$ & 52 & $63.72^{b}$ & 11.59 & 6.02 & 601.68 & \\
\hline & Total & 380 & 26.53 & 2.01 & .00 & 601.68 & \\
\hline \multirow{5}{*}{$\begin{array}{l}\text { Chicken meat } \\
\text { expenditures }\end{array}$} & $\leq 300 \$$ & 112 & $14.74^{a}$ & 1.28 & .00 & 60.17 & \multirow{5}{*}{$\begin{array}{l}F=8.390 \\
P=0.000 \\
P<0.001\end{array}$} \\
\hline & $301-600 \$$ & 136 & $16.94^{a}$ & 1.26 & .00 & 60.17 & \\
\hline & $601-900 \$$ & 80 & $17.40^{a}$ & 1.30 & .00 & 84.24 & \\
\hline & $\geq 901 \$$ & 52 & $26.19^{b}$ & 2.07 & 4.81 & 90.25 & \\
\hline & Total & 380 & 17.66 & 0.73 & .00 & 90.25 & \\
\hline \multirow{5}{*}{ Fish expenditures } & $\leq 300 \$$ & 112 & $5.94^{a}$ & 0.57 & .00 & 36.10 & \multirow{5}{*}{$\begin{array}{c}F=22.158 \\
P=0.000 \\
P<0.001\end{array}$} \\
\hline & $301-600 \$$ & 136 & $7.44^{a}$ & 0.75 & .00 & 60.17 & \\
\hline & $601-900 \$$ & 80 & $9.92^{b}$ & 0.88 & .00 & 36.10 & \\
\hline & $\geq 901 \$$ & 52 & $18.03^{c}$ & 2.16 & .00 & 60.17 & \\
\hline & Total & 380 & 8.97 & 0.51 & .00 & 60.17 & \\
\hline \multirow{5}{*}{$\begin{array}{l}\text { Milk and dairy products } \\
\text { expenditures }\end{array}$} & $\leq 300 \$$ & 112 & $8.97^{a}$ & 0.56 & .00 & 24.07 & \multirow{5}{*}{$\begin{array}{c}F=0.33 \\
P=0.804 \\
P>0.05\end{array}$} \\
\hline & $301-600 \$$ & 136 & $9.08^{a}$ & 0.44 & 1.20 & 30.08 & \\
\hline & $601-900 \$$ & 80 & $8.61^{a}$ & 0.50 & 2.41 & 18.05 & \\
\hline & $\geq 901$ \$ & 52 & $9.51^{a}$ & 0.64 & 3.01 & 24.07 & \\
\hline & Total & 380 & 9.01 & 0.26 & .00 & 30.08 & \\
\hline
\end{tabular}

*1 \$= 8.31 TL (Date: September 07, 2021/TCMB [The Central Bank of the Republic of Turkey], 2021), a,b,c,d: The difference between the mean values shown with different letters according to income groups for the same parameter is statistically significant. 


\begin{tabular}{|c|c|c|c|c|}
\hline The animal products consumed* & Income level & Mean & Std. Error & F/P value \\
\hline \multirow{5}{*}{ Beef } & $\leq 300 \$$ & $6.03^{a}$ & 0.89 & \multirow{5}{*}{$\begin{array}{c}F=16.740 \\
P=0.000 \\
P<0.001\end{array}$} \\
\hline & $301-600 \$$ & $9.35^{a}$ & 1.08 & \\
\hline & $601-900 \$$ & $11.20^{b}$ & 1.40 & \\
\hline & $\geq 901 \$$ & $15.59 c$ & 2.29 & \\
\hline & Total & 9.31 & 0.67 & \\
\hline \multirow{5}{*}{ Mutton-lamb } & $\leq 300 \$$ & $4.25^{a}$ & 0.66 & \multirow{5}{*}{$\begin{array}{c}F=2.809 \\
P=0.049 \\
P<0.05\end{array}$} \\
\hline & $301-600 \$$ & $5.88^{a}$ & 0.88 & \\
\hline & $601-900 \$$ & $4.78^{a}$ & 0.86 & \\
\hline & $\geq 901 \$$ & $9.00^{b}$ & 1.57 & \\
\hline & Total & 5.89 & 0.46 & \\
\hline \multirow{5}{*}{ Chicken meat } & $\leq 300 \$$ & $15.59^{a}$ & 1.60 & \multirow{5}{*}{$\begin{array}{c}F=0.114 \\
P=0.952 \\
P>0.05\end{array}$} \\
\hline & $301-600 \$$ & $16.37^{a}$ & 1.45 & \\
\hline & $601-900 \$$ & $16.27^{a}$ & 1.72 & \\
\hline & $\geq 901 \$$ & $19.57^{a}$ & 2.43 & \\
\hline & Total & 16.94 & 0.85 & \\
\hline \multirow{5}{*}{ Milk-yogurt } & $\leq 300 \$$ & $29.55^{a}$ & 2.01 & \multirow{5}{*}{$\begin{array}{c}F=12.320 \\
P=0.000 \\
P<0.001\end{array}$} \\
\hline & $301-600 \$$ & $38.82^{b}$ & 1.72 & \\
\hline & $601-900 \$$ & $38.27^{b}$ & 2.00 & \\
\hline & $\geq 901 \$$ & $48.94^{c}$ & 2.19 & \\
\hline & Total & 37.38 & 1.04 & \\
\hline \multirow{5}{*}{ Cheese } & $\leq 300 \$$ & $15.34^{a}$ & 1.19 & \multirow{5}{*}{$\begin{array}{c}F=12.493 \\
P=0.000 \\
P<0.001\end{array}$} \\
\hline & $301-600 \$$ & $22.27^{b}$ & 1.07 & \\
\hline & $601-900 \$$ & $22.49^{b}$ & 1.21 & \\
\hline & $\geq 901 \$$ & $26.23^{b}$ & 1.50 & \\
\hline & Total & 20.84 & 0.64 & \\
\hline \multirow{5}{*}{$\begin{array}{l}\text { Eggs } \\
\text { (unit) }\end{array}$} & $\leq 300 \$$ & $82.15^{a}$ & 18.36 & \multirow{5}{*}{$\begin{array}{l}F=7.949 \\
P=0.000 \\
P<0.001\end{array}$} \\
\hline & $301-600 \$$ & $180.52^{b}$ & 19.25 & \\
\hline & $601-900 \$$ & $188.12^{b}$ & 19.93 & \\
\hline & $\geq 901 \$$ & $217.32^{b}$ & 25.20 & \\
\hline & Total & 168.27 & 10.60 & \\
\hline
\end{tabular}

$*$ : The data of the participants who stated that they never consumed the product were not included in the calculation of the average value. $a, b$ The difference between the mean values shown with different letters according to income groups for the same parameter is statistically significant.

According to the Agricultural Products Market Report, $13.3 \mathrm{~kg}$ of beef is consumed per capita in Turkey (TEPGE, 2021). Although Turkey is above the world average $(6.4 \mathrm{~kg})$ in beef consumption, it falls behind many countries, such as Argentina, Australia, the US, European Union, Russia, Israel, in total red meat consumption due to the high consumption of pork in many developed and developing countries (OECD, 2021). One of the main reasons for the low consumption of red meat in Turkey is the high production costs and price compared to other foods (Taskin et al., 2020).

It was determined that the students in the study consumed an average of $15.20 \mathrm{~kg}$ of red meat $(9.31 \mathrm{~kg}$ of beef and $5.89 \mathrm{~kg}$ of mutton-lamb) annually. It is thought that one of the most important reasons why this finding was lower than beef consumption $(13.3 \mathrm{~kg})$ and higher than mutton-lamb consumption $(1.5 \mathrm{~kg})$ per capita in Turkey is that $52.9 \%$ of the students in the study lived in provinces in the Eastern and Southeastern Anatolia Regions (TEPGE, 2021). As a matter of fact, considering the geographical location of the provinces, some studies have indicated that people in the provinces of the Eastern and Southeastern Anatolia Regions often consume red meat and that they mostly prefer mutton (Karakus et al., 2008; Tosun and Hatirli, 2009; Seker et al., 2011; Kara et al., 2020).

In the study, it was found that the students' annual consumption of chicken meat and mutton did not change significantly, except for those with a monthly income of $\geq \$ 900$. Similarly, a study conducted in Gaziantep showed that regardless of the difference between income levels, income subgroups also consumed mutton at rates close to each other (Karakus et al., 2008). 
Chicken meat is widely consumed in Turkey due to its cooking time, ease of cooking, and more affordable price than red meat (BESD-BIR, 2021). According to the 2020 data of BESD-BIR (2021) compared to the total world poultry meat production of 132 million tons, Turkey ranks in the top 10 countries in the world with a production of 2 million 194 thousand tons, and the annual per capita consumption of poultry meat is $21.10 \mathrm{~kg}$. In the study, it was evaluated that the students consumed chicken meat below the Turkey average with an annual average consumption of $16.94 \mathrm{~kg}$ of chicken meat. The amount of chicken meat consumption in the study was found to be higher than the findings of the studies conducted in Kırşehir, Amasya, and Sivas provinces (Kizilaslan and Nalinci, 2013; Karadavut and Taskin, 2014; Bircan et al., 2017) and lower than the findings of the studies conducted in Kahramanmaraş, Bingöl, and Yozgat provinces (Karakaya and Inci 2014; Tumer et al., 2016; Eleroglu et al., 2018). This can be explained by the fact that the students consumed relatively more mutton than the Turkey average (TEPGE, 2021).

In the study, it was calculated that the students consumed an average of 168 eggs per year, and this value remained at a lower level than the overall average of Turkey, which was reported as 214 eggs per year (YUM-BIR, 2018). The difference between the average annual egg consumption per capita in Turkey and the research data is thought to be due to the inclusion of indirect consumption (cake, biscuit, etc.) in the average annual consumption value in Turkey. On the other hand, the average annual egg consumption per capita reported in the studies conducted in Yozgat (Eleroglu et al., 2018), Bingöl (Inci et al., 2014), Sivas (Bircan et al., 2017), and Uşak (Parlakay et al., 2017) provinces as 130.49, 146.3, 123.4, and 102, respectively, was lower than the average annual egg consumption per capita calculated in the present study. In line with these findings, it can be said that the egg, which is known as the cheapest protein source, is widely consumed among students.

Today, there is an increase in the demand for milk and dairy products due to the increase in awareness and income level. However, in the study, it was determined that the majority of the students (about $75 \%$ ) did not consume milk regularly and preferred yogurt and cheese more. Similarly, some studies in the literature have reported that students do not have regular milk consumption habits (Engindeniz et al., 2021).

In the study, it was determined that the students consumed an average of $37.38 \mathrm{~kg}$ of milk and yogurt per capita per year. The annual per capita consumption of yogurt was found as $32.84 \mathrm{~kg}$ by Engindeniz et al. (2021), 31.96 kg by Karakaya and Akbay (2013), and $27.66 \mathrm{~kg}$ by Andic et al. (2002). It is thought that the finding of the present study was high due to the inclusion of milk consumption in the average annual consumption per capita in the study. On the other hand, Savran et al. (2011) reported average milk consumption as $64 \mathrm{l} /$ year and yogurt consumption as $55 \mathrm{~kg} / \mathrm{year}$.

In the study, the average annual cheese consumption of the participants was determined as $20.84 \mathrm{~kg}$. This value was above the average annual cheese consumption amount (17.5 kg) per capita in Turkey in 2019 (USK, 2020). Although this difference is thought to be regional, it can be said that cheese and yogurt consumption is common in the provinces in the Eastern and Southeastern Anatolia Regions. On the other hand, the average annual cheese consumption per capita was reported as $18.48 \mathrm{~kg}$ by Engindeniz et al. (2021), $23 \mathrm{~kg}$ by Savran et al. (2011), 14.65 kg by Karakaya and Akbay (2013), and $17.63 \mathrm{~kg}$ by Andic et al. (2002).

The reasons for consuming red meat and chicken meat by the students are given in Table 4. As seen in Table 4, being healthy-nutritious ranks first among the reasons why the participants consumed red meat. This is followed by being tasty, habit, and availability, respectively. Among the reasons for consumption of chicken meat, being healthy and tasty rank first and second place, respectively, and low price ranks the third place. Similar to the results of this study, Karakus et al. (2008) found being nutritious as the first ranking characteristic, and Seker et al. (2011) determined being tasty as the most prominent parameter. In line with these data, it can be said that the participants had an awareness of consuming animal products in that they found them both healthy and tasty.

The ranking of the participants' preference for some animal products is given in Table 5.

As seen in Table 5, the red meat products that students preferred most were minced, flaked, and bony and the most preferred three chicken products were whole chicken, breast meat, and chicken legs, respectively. In addition, the most preferred milk types were organic milk, pasteurized, and long-life milk, and the most preferred egg types or common reasons for buying eggs included affordable price, organic eggs, and cage-free chicken eggs, respectively.

According to the findings, the primary red meat products that students preferred were minced meat, flaked meat, and meat with bones. In parallel with this research finding, Taskin et al. (2020) reported similar product rankings. In the study, it can be said that the consumption of minced meat as a red meat product more than other red meat preparations was because minced meat was used in various types of food and its price was affordable. In the study, it was found that the chicken products that students preferred most were whole chicken and breast meat and that the findings were similar to those of other studies (Iskender et al., 2015; Kara et al., 2020). It is thought that the tendency of the participants towards cheap products in chicken meat was related to their income level.

In the study, it was determined that $7.10 \%$ of the participants did not consume red meat, $2.37 \%$ did not consume chicken meat, $\mathbf{1 . 5 8} \%$ did not consume milk, and that $\mathbf{2 . 3 7 \%}$ did not consume eggs. In parallel with the results of the study, Sancak and Basat Dereli (2019) determined that $7.6 \%$ of their participants did not consume meat, and this rate was found as $6 \%$ by Kusat and Sahan (2021). On the other hand, according to a report of the Ministry of Health of the Republic of Turkey and Hacettepe University (2014), 20.2\% of the population does not consume red meat. Differences in red meat consumption can be explained by the change of consumption habits according to regions and urban-rural settlements. The rate of those who do not consume other animal products is between 1-3\%, which is considered as a positive development in terms of health. 
Table 4 - Reasons for consuming red meat and chicken meat

\begin{tabular}{lcccc}
\multirow{2}{*}{ Parameter } & \multicolumn{2}{c}{ Reasons for consuming red meat } & \multicolumn{2}{c}{ Reasons for consuming chicken meat } \\
\cline { 2 - 5 } & Frequency & Ranking & Frequency & Ranking \\
\hline Healthy- nutritious & 276 & 1 & 194 & 1 \\
Tasty & 170 & 2 & 140 & 2 \\
Habit & 75 & 3 & 76 & 5 \\
Availability & 34 & 4 & 109 & 4 \\
Low price & 0.0 & - & 136 & 3 \\
Easy to cook & 0.0 & - & 58 & 6 \\
\hline
\end{tabular}

Table 5 - The ranking of the participants' preference for some animal products

\begin{tabular}{|c|c|c|c|c|c|}
\hline \multicolumn{3}{|c|}{ The most preferred products when buying red meat } & \multicolumn{3}{|c|}{ The most preferred products when buying chicken meat } \\
\hline Product & Frequency & Ranking & Product & Frequency & Ranking \\
\hline Minced & 225 & 1 & Whole chicken & 158 & 1 \\
\hline Flaked & 154 & 2 & Breast meat & 144 & 2 \\
\hline Bony & 94 & 3 & Chicken legs & 124 & 3 \\
\hline Sausages-salami & 76 & 4 & Wings & 111 & 4 \\
\hline Tenderloin, chops & 72 & 5 & Drumsticks & 52 & 5 \\
\hline Lamb neck & 24 & 6 & Chops & 42 & 6 \\
\hline No consumption & 27 & $7.10 \%$ & No consumption & 9 & $2.37 \%$ \\
\hline \multicolumn{3}{|c|}{ The most preferred milk type or common reasons for buying milk } & \multicolumn{3}{|c|}{ The most common reasons for buying eggs } \\
\hline Product & Frequency & Ranking & Product & Frequency & Ranking \\
\hline Organic milk & 221 & 1 & Affordable & 122 & 1 \\
\hline Pasteurized & 129 & 2 & Organic & 114 & 2 \\
\hline Long life (UHT) & 113 & 3 & Cage-free chicken eggs & 66 & 3 \\
\hline Milkman delivery & 79 & 4 & Size & 20 & 4 \\
\hline Affordable & 64 & 5 & Color & 10 & 5 \\
\hline Any type & 12 & 6 & Any type & 81 & 6 \\
\hline No consumption & 6 & $1.58 \%$ & No consumption & 9 & $2.37 \%$ \\
\hline
\end{tabular}

The rate of change in food and animal product consumption during the pandemic compared to the pre-pandemic period is given in Table 6 .

As seen in Table 6 , the total food consumption of $55.3 \%$ of the participants and the animal products consumption of $35.8 \%$ of them increased during the pandemic. In the study, it was observed that the consumption of food and animal products increased as the income level of the participants increased during the pandemic compared to the pre-pandemic period, and the difference between the terms was statistically significant $(P<0.001)$. In line with the research findings, Naja and Hamadeh (2020) stated that a protein-rich diet that is also rich in fresh fruits and vegetables was necessary to keep the infection away and support the immune system.

In the study, those who stated that their consumption of animal products increased attributed this increase to regular and balanced nutrition at home (47.06\%), additional eating to increase body resistance (41.18\%), and restaurants that were closed during lockdowns (11.76\%). Those who stated that their consumption of animal products decreased attributed this decrease to the decrease in household income level (64.71\%) and other reasons (35.29\%).

The changes and rates of consumption of some animal products during the pandemic are given in Table 7.

As can be seen in Table 7, there was no change in the amount of animal products consumption between $42.1 \%$ and 49.2\%, although it varied according to the participants' parameters. In the study, it was determined that the red meat and salami-sausages consumption of $31.8 \%$ of the students decreased by $37.90 \%$ and $42.15 \%$, respectively. Similarly, Taskin et al. (2020) reported that students' red meat consumption decreased by $56.4 \%$ compared to the previous year. Ersoy and Yardimci (2020) reported that the COVID-19 pandemic negatively affected nutrition, especially in low- and middle-income groups.

It was determined in the current study that the chicken meat consumption of $31.3 \%$ of the participants and milk and dairy products consumption of $37.9 \%$ increased by $31.02 \%$ and $39.17 \%$, respectively, during the pandemic. This result was close to the results of Unal et al. (2020) who reported that more food was cooked during quarantine times and that the time allocated for cooking and the types of food that were cooked increased. Similarly, Dilber and Dilber (2020) found that the number of snacks and main meals that individuals consumed increased and that the most consumed foods were pastries and meat and meat products. On the other hand, in his study in which students' eating habits during the pandemic were evaluated, Erdoğan (2021) reported that $45.5 \%$ of the students had changes in their eating habits, $50.6 \%$ consumed two main meals a day, and $63.6 \%$ had breakfast regularly. Kriaucioniene et al. (2020) found that during the 
COVID-19 quarantine period in Lithuania, participants ate more food than usual at home, snacked more, and cooked at home more often.

It can be said that the new normal lifestyle and rules have emerged in Turkey during the coronavirus pandemic, along with the structural and social changes that include education, working life, social relationships, and consumption preferences (Unal et al., 2020). During the lockdowns in the pandemic, authorities in the broadcasts and television programs recommended paying attention to adequate and balanced nutrition, consuming animal proteins such as meat and fish at least twice a week, and preferring healthy foods to reduce the sensitivity and long-term complications caused by the coronavirus (Butler and Barrientos, 2020; Unal et al., 2020).

\begin{tabular}{|c|c|c|c|c|c|c|c|}
\hline \multirow{2}{*}{ Income groups } & \multicolumn{3}{|c|}{ Food consumption in the pandemic } & \multicolumn{3}{|c|}{ Animal product consumption in the pandemic } & \multirow[t]{2}{*}{ Total } \\
\hline & Increased & Decreased & No change & Increased & Decreased & No change & \\
\hline \multirow{2}{*}{$\leq 300 \$$} & 55 & 35 & 22 & 24 & 50 & 38 & 112 \\
\hline & $49.1 \%$ & $31.2 \%$ & $19.6 \%$ & $21.4 \%$ & $44.6 \%$ & $33.9 \%$ & $100.0 \%$ \\
\hline \multirow{2}{*}{$301-600 \$$} & 71 & 36 & 29 & 52 & 34 & 50 & 136 \\
\hline & $52.2 \%$ & $26.5 \%$ & $21.3 \%$ & $38.2 \%$ & $25.0 \%$ & $36.8 \%$ & $100.0 \%$ \\
\hline \multirow{2}{*}{$601-900 \$$} & 47 & 7 & 26 & 38 & 14 & 28 & 80 \\
\hline & $58.8 \%$ & $8.8 \%$ & $32.5 \%$ & $47.5 \%$ & $17.5 \%$ & $35.0 \%$ & $100.0 \%$ \\
\hline \multirow{2}{*}{$\geq 901 \$$} & 37 & 3 & 12 & 22 & 4 & 26 & 52 \\
\hline & $71.2 \%$ & $5.8 \%$ & $23.1 \%$ & $42.3 \%$ & $7.7 \%$ & $50.0 \%$ & $100.0 \%$ \\
\hline \multirow{2}{*}{ Total } & 210 & 81 & 89 & 136 & 102 & 142 & 380 \\
\hline & $55.3 \%$ & $21.3 \%$ & $23.4 \%$ & $35.8 \%$ & $26.8 \%$ & $37.4 \%$ & $100.0 \%$ \\
\hline $\mathrm{X}^{2} / \mathrm{P}$ value & \multicolumn{3}{|c|}{$X^{2}=26.009 P=0.000 P<0.001$} & \multicolumn{4}{|c|}{$X^{2}=36.171 P=0.000 P<0.001$} \\
\hline
\end{tabular}

Table 7 - The effect of the pandemic on the consumption level of some animal products

\begin{tabular}{|c|c|c|c|c|c|c|}
\hline \multirow{2}{*}{$\begin{array}{l}\text { Status of } \\
\text { change }\end{array}$} & \multicolumn{3}{|c|}{ Red Meat Consumption during the Pandemic } & \multicolumn{3}{|c|}{ Chicken Meat Consumption during the Pandemic } \\
\hline & Frequency & Percentage & $\%$ Variance & Frequency & Percent & $\%$ Variance \\
\hline Increased & 99 & 26.1 & 30.55 & 119 & 31.3 & 31.02 \\
\hline Decreased & 121 & 31.8 & 37.90 & 98 & 25.8 & 29.05 \\
\hline No change & 160 & 42.1 & - & 163 & 42.9 & - \\
\hline \multirow{2}{*}{$\begin{array}{l}\text { Status of } \\
\text { change }\end{array}$} & \multicolumn{3}{|c|}{$\begin{array}{l}\text { Consumption of Milk and Dairy Products during the } \\
\qquad \text { Pandemic }\end{array}$} & \multicolumn{3}{|c|}{$\begin{array}{l}\text { Consumption of Sausages and Salami during the } \\
\text { Pandemic }\end{array}$} \\
\hline & Frequency & Percentage & $\%$ Variance & Frequency & Percentage & $\%$ Variance \\
\hline Increased & 144 & 37.9 & 39.17 & 72 & 18.9 & 28.62 \\
\hline Decreased & 64 & 16.8 & 21.94 & 121 & 31.8 & 42.15 \\
\hline No change & 172 & 45.3 & - & 187 & 49.2 & - \\
\hline
\end{tabular}

\section{CONCLUSION}

In conclusion, it was determined that there were significant changes in the nutritional habits of the students during the COVID-19 pandemic and that there were significant increases in the consumption of animal products other than red meat. The main reason why red meat consumption did not increase is thought to be due to the high price of the product compared to the income of the consumers. In this context, consumption of red meat, not as a luxury product but as a basic need, in every part of society seems possible only if the prices are brought to an affordable level. It is necessary to reduce producer input costs and the number of dealers in the marketing chain so that prices can go down and consumers can buy red meat as much as they want. 


\section{DECLARATIONS}

Corresponding author

Erol Aydin: E-mail: dr-erolaydin@hotmail.com; ORCID ID: 0000-0001-8427-5658

\section{Funding support}

No financial support was received.

\section{Conflict of interest}

The authors declare that they have no competing interests.

\section{Authors' collaboration}

E. Aydin and P. Ayvazoglu Demir planned and designed the research and contributed to the collection of online data. P. Ayvazoglu Demir analyzed the data. E. Aydin wrote the manuscript. All authors discussed the results and contributed to the final manuscript.

\section{REFERENCES}

Akin AC, Arikan MS, Cevrimli MB, Tekindal MA (2020). Assessment of the effect of beef and mutton meat prices on chicken meat prices in Turkey using different regression models and the decision tree algorithm. Kafkas Universitesi Veteriner Fakultesi Dergisi, 26(1): 47-52, DOI: https://doi.org/10.9775/kvfd.2019.22195

Akin AC, Cevrimli MB, Mat B, Arikan MS, Tekindal MA (2019). Factors Affecting Poultry Meat Consumption Status and Consumption Habits of Students From Faculty of Veterinary Medicine. Kocatepe Veterinary Journal, 12(4): 456-462, DOI: https://doi.org/10.30607/kvi.639871

Aktas AR and Hatirli SA (2010). Analysis of Meat Demand in Urban Area: Evidence from West Mediterrenian Region. Journal of Yasar University, 5: 3294-331. Link: https://journal.yasar.edu.tr/wp-content/uploads/2012/08/09_ali_riza_aktas.pdf

Aktas G (2020). Effect of the Importing Livestock and Carcass on the Red Meat Price: The Import Regulations in Turkey. Gumruk Ticaret Dergisi, 7(21): 12-29. Link: https://dergipark.org.tr/en/download/article-file/1253896

Andic S, Sahin K and Koc S (2002). Milk Consumption in Van Province. Yuzuncu Yil Universitesi Ziraat Fakultesi Tarim Bilimleri Dergisi, 12(2): 33-38. Link: https://dergipark.org.tr/en/download/article-file/204953

Andrews JL, Foulkes L and Blakemore SJ (2020). Peer influence in adolescence: Public-health implications for COVID-19. Trends in Cognitive Sciences, 24(8): 585-587. DOI: https://doi.org/10.1016/i.tics.2020.05.001

BESD-BIR (2021). Association of Poultry Meat Producers and Breeders, Statistics. Link: https://besd-bir.org/tr/statistikler

Bircan H, Eleroglu H and Arslan R (2017). The Consumption of Poultry Products in Sivas Province and Factors Affecting on the Consumption. Turkish Journal of Agriculture - Food Science and Technology, 5(12): 1609-1614. DOI: https://doi.org/10.24925/turjaf.v5i12.1609-1614.1721

Butler MJ and Barrientos RM (2020). The impact of nutrition on COVID-19 susceptibility and long-termconsequences. Brain, Behavior, and Immunity, 87: 53-54. DOI: https://doi.org/10.1016/j.bbi.2020.04.040

Celik Y and Sengul T (2001). Determination of Level of Egg Consumption and Consumption Pattern of Consumers in Şanlıurfa Urban Areas. Hayvansal Uretim, 42(2): 53-62. Link: https://dergipark.org.tr/en/download/article-file/85196

Charlebois S, Schwab A, Henn R and Huck CW (2016). Food fraud: An exploratory study for measuring consumer perceptiontowards mislabeled food products and influence on self-authentication intentions. Trends in Food Science \& Technology, 50: 211-218, DOI: http://doi.org/10.1016/j.tifs.2016.02.003

Demir Ayvazoglu P and Aydin E (2021). Generation Z's Perspective on animal Product Consumption. 3nd Internatıonal Cukurova Agriculture and Veterınary Congress, Pages: 942-949, October 9-10 2021, Adana, Turkey.

Dilber A and Dilber F (2020). The Effect of Coronavirus (COVID-19) Disease on the Nutritional Habits of Individuals: The Case of Karaman Province. Journal of Tourism and Gastronomy Studies, 8(3): 2144-2162. DOI: https://doi.org/10.21325/jotags.2020.653

Eleroglu H, Bircan H and Arslan R (2018). The Factors Affecting Egg and Poultry Meat Consumption in Yozgat Province. Tavukculuk Arastirma Dergisi, 15(1): 29-33. Link: https://dergipark.org.tr/en/download/article-file/512246

Engindeniz S, Taskin T, Gbadamonsi AA, Ahmed AS, Saloum Cisse A, Seioudy AF, Kandemir C and Kosum N (2021). Analysis of Preferences for Milk and Milk Products of Consumers. Journal of Tekirdag Agricultural Faculty, 18(3): 470-481. D0I: https://doi.org/10.33462/jotaf.841924

Erdoğan R (2021). Determination of The Nutritional Habits and Physical Activity Levels of The Students of The School of Physical Education and Sport During the Pandemic Period. International Journal of Society Researches, 17(special isue): 3276-3295. DOI: https://doi.org/10.26466/opus.862585

Ersoy N and Yardimci H (2020). The impact of COVID-19 on childhood malnutrition. Health in Different Dimensions (in Turkish), Editor: Akgöl J, Pages 1-9, Soncag Publishing, Çanakkale, E-ISBN: 978-625-7047-35-7 .

Inci H, Karakaya E, Sengul T and Sogut B (2014). The Structure of Poultry Meat Consumption in Bingöl. Turk Tarim ve Doga Bilimleri Dergisi, 1(1): 17-24. Link: https://dergipark.org.tr/en/download/article-file/142093

Iskender H, Kanbay Y and Ozcelik E (2015). Consumer Preference for Chicken Meat among the Students of Artvin Coruh University, Firat Universitesi Saglik Bilimleri Veteriner Dergisi, 29(1): 09-13. Link: http://veteriner.fusabil.org/pdf/pdf_FUSABIL_1020.pdf

Kara MA, Tekeli A and Mikail N (2020). Chicken Meat Consumption Habits of University Students: Case of Siirt University, Turkey. Turkish Journal of Agriculture Research, 7(3): 327-336. Dol: https://doi.org/10.19159/tutad.794722

Karadavut U and Taskin A (2014). Determination of Factors Affecting Poultry Meat Consumption in Kırşehir Province. Journal of Tekirdag Agricultural Faculty, 11(1): 37-43. Link: https://dergipark.org.tr/en/download/article-file/178306 
Karakaya E and Akbay C (2013). Consumer Consumption Habits Of Milk and Milk Products in Istanbul Province. Journal of Agricultural Faculty of Uludag University, 27(1): 65-77. Link: https://dergipark.org.tr/en/download/article-file/154182

Karakaya E and Inci H (2014). The Preferences of Poultry Meat Consumption of Household in Central District of Bingöl. Journal of Agricultural Faculty of Uludag University, 28(1): 53-64. Link: https://dergipark.org.tr/en/download/article-file/154211

Karakus K, Aygun T and Alarslan E (2008). Consumption Habits of Meat in Centre Town of Gaziantep Province. Yuzuncu Yil Universitesi Ziraat Fakultesi Tarim Bilimleri Dergisi, 18(2): 113-120. Link: https://dergipark.org.tr/en/download/articlefile/204833

Kizilaslan H and Nalinci S (2013). The Poultry Consumption Habits of Households and the Factors Affecting Their Poultry Consumption in the Province of Amasya. Gaziosmanpasa Bilimsel Araştırma Dergisi, 6:1-18. Link: https://dergipark.org.tr/en/download/article-file/311611

Kriaucioniene V, Bagdonaviciene L, Rodríguez-Pérez C and Petkeviciene J (2020). Associations between Changes in Health Behaviours and Body Weight during the COVID-19 Quarantine in Lithuania: The Lithuanian COVIDiet Study. Nutrients, 12(10): 3119. DOI: https://doi.org/10.3390/nu12103119

Kusat M and Sahan M (2021). Su ürünleri tüketim tercihleri üzerine Uşak ilinde bir anket çalışması. Acta Aquatica Turcica, 17(3): 376-385. DOI: https://doi.org/10.22392/actaquatr.848663

Ministry of Health of the Republic of Turkey (2020). General Directorate of Public Health. CoVID-19 (Sars-Cov-2 Infection) General Information, Epidemiology and Diagnosis. Ankara, Turkey. Link

Ministry of Health of the Republic of Turkey and Hacettepe University (2014). Nutrition and Health Survey in Turkey-TBSA Nutritional Status and Habits Evaluation Final Report (in Turkish). Ministry of Health Publication No: 931, Ankara, Turkey. Link: https://hsgm.saglik.gov.tr/depo/birimler/saglikli-beslenme-hareketli-hayat-db/Yayinlar/kitaplar/diger-kitaplar/TBSABeslenme-Yayini.pdf

Naja F and Hamadeh R (2020). Nutrition amid the COVID-19 pandemic a multi-level framework for action. European Journal of Clinical Nutrition, 74: 1117-1121. DOI: https://doi.org/10.1038/s41430-020-0634-3

OECD (2021). Organisation for Economic Co-operation and Development, Meat Consumption. Link: https://data.oecd.org/agroutput/meat-consumption.htm

Parlakay O, Arslan Duru A and Akin Y (2017). Determination of Egg Consumption Preferences of Consumers: The Case of Uşak Province, Turkey. Journal of Agricultural Faculty of Gaziosmanpasa University, 34(2): 108-115. DOI: https://doi.org/10.13002/jafag4289

Sancak H and Basat Dereli D (2019). Opinion and Behaviors of Tatvan Vocational School Students About Milk and Milk Consumption. Harran Universitesi Veteriner Fakultesi Dergisi, 8(1): 7-15. DOI: https://doi.org/10.31196/huvfd.590872

Saul AW (2020). Nutritional treatment of coronavirus. Orthomolecular Medicine News Service, 16(6): 22. Link: https://drlauda.at/images/pdf/omns/Nutritional_Treatment_of_Coronavirus.pdf

Savran F, Akturk D, Dellal I, Tatlidil F, Dellal G and Pehlivan E (2011). The Factors Eff ected on Consumption of Goat Milk and Its Products in Some Selected Cities in Turkey. Kafkas Üniversitesi Veteriner Fakültesi Dergisi, 17(2): 251-256. DOI: https://doi.org/10.9775/kvfd.2010.3177

Seker I, Ozen A, Guler H, Seker P and Ozden I (2011). Red Meat Consumption Behavior in Elazığ and Consumers' Opinion in Animal Welfare. Kafkas Universitesi Veteriner Fakultesi Dergisi, 17(4): 543-550. DOI: http://doi.org/10.9775/kvfd.2010.3825

Sengul S (2002). Food demand by income groups in urban and rural areas in Turkey (in Turkish). Uludag Universitesi Iktisadi ve Idari Bilimler Fakultesi Dergisi, 21(1): 257-282. Link: https://acikerisim.uludag.edu.tr/bitstream/11452/17715/1/21 1114.pdf

Taskin T, Engindeniz S, Gbadamonsi AA, Kandemir C and Kosum N (2020). Analysis of Red Meat Consumption Preferences of Youth: A Case Study for Ege University Students. Ege Universitesi Ziraat Fakultesi Dergisi, 57(1): 63-71. DOI: https://doi.org/10.20289/zfdergi.587525

TCMB (2021). The Central Bank of the Republic of Turkey, Exchange rate data. Link: https://www.tcmb.gov.tr/kurlar/kurlar_tr.html

TEPGE (2021). TR Ministry of Agriculture and Forestry, Directorate of Agricultural Economy and Policy Development Institute, Ovine Meat Report. Link: https://arastirma.tarimorman.gov.tr/tepge/Belgeler

Tosun 00 and Hatirli SA (2009). An Analysis of Red Meat Purchasing Preferences of Households in Antalya. Suleyman Demirel University The Journal of Faculty of Economics and Administrative Sciences, 14(2): 433-445. Link: https://dergipark.org.tr/en/download/article-file/194677

Tumer El, Akbay C, Kosum A and Unal SA (2016). Chicken Meat Consumption Habits and the Factors Affecting Consumption in Kahramanmaraş Province. KSU Journal of Natural Sciences, 19(4): 433-43. Link: https://dergipark.org.tr/en/download/article-file/230711

Unal E, Ozdemir A, Yuksel Kacan C (2020). Impact of the Covid-19 Pandemic on Feeding and Hygiene Habits of Nursing Students. Uludag Universitesi Tip Fakultesi Dergisi, 46(3): 305-311. DOI: https://doi.org/10.32708/uutfd.791891

USK (2020). Turkish National Dairy Council, 2019 Milk Report, Dairy Industry Statistics in the World and Turkey. Ankara, Turkey. Link: https://ulusalsutkonseyi.org.tr/en/

Uzunoz M and Karakas G (2014). Socio-economic Determinants of Red Meat Consumption in Turkey: A Case Study. Cankiri Karatekin Universitesi Sosyal Bilimler Enstitusu Dergisi, 5(1): 37-52. Link: https://dergipark.org.tr/tr/download/articlefile/253897

YUM-BiR (2018). Egg Producers Central Association, Layer Poultry Data. Link: https://www.yum-bir.org/UserFiles/File/yumurtaveriler2019web.pdf

Zhang $L$ and Liu Y (2020). Potential interventions for novel coronavirus in China: A systematic review. Journal Medical Virology, 92(5): 479-90. DOI: https://doi.org/10.1002/jmv.25707 